\title{
Karakteristik radiograf kista dentigerous dengan menggunakan CBCT-scan
}

\author{
Berty Pramatika" (iD, Aga Satria Nurrachman² (iD, Eha Renwi Astuti ${ }^{3}$ iD
}

\begin{abstract}

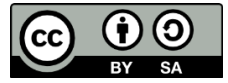

Objectives: The aim of this report which contains three case series is to describe the radiographic characteristic of dentigerous cyst using CBCT.

Case Report: In the case presented here, all of the three patients had dentigerous cyst developing in impacted tooth, but did not have the same symptoms. CBCT radiography examination was carried out to find out the margin of the cortical extension, the diameter of the lesion, and the

relations between the lesion and adjacent structures. The result of CBCT examination shows there is a variation of radiograph characteristics of dentigerous cyst among the three patients.

Conclusion: CBCT is a very useful complementary tool for diagnosis and surgical planning in cases of dentigerous cyst, because three-dimensional viewing of the structures offers greater accuracy in lesion identification.
\end{abstract}

This work is licensed under a Creative Commons Attribution 4.0

${ }^{1}$ Rumah Sakit Universitas Brawijaya Malang, Indonesia 65141

${ }^{2}$ PPDGS Radiologi Kedokteran Gigi, Fakultas Kedokteran Gigi, Universitas Padjadjaran, Bandung, Indonesia 40132

${ }^{3}$ Departemen Radiologi Kedokteran Gigi, Fakultas Kedokteran Gigi, Universitas Airlangga, Surabaya, Indonesia, 60132

${ }^{*}$ Correspondence to:

Berty Pramatika

凶berty.pram@gmail.com

Received on: June 2020

Revised on: July 2020

Accepted on: August 2020

\section{Keywords: dentigerous cyst, impacted tooth, $C B C T$, radiograph characteristics}

Cite this article: Pramatika B, Nurrachman AS, Astuti ER. Karakteristik radiograf kista dentigerous dengan menggunakan CBCT-scan. Jurnal Radiologi Dentomaksilofasial Indonesia 2020;4(2)15-20. https://doi.org/10.32793/jrdi.v4i2.519

\section{PENDAHULUAN}

Kista dentigerous atau juga disebut sebagai kista folikuler merupakan salah satu kista perkembangan yang terbentuk pada bagian mahkota gigi yang tidak erupsi. Kista dentigerous pertama kali dilaporkan pada tahun 1853 oleh Paget dan dikenal sebagai kapsul yang membengkak, osseous cyst atau serous cyst. Prevalensi kista dentigerous sekitar $24 \%$ dari seluruh true cyst pada rahang, kedua tertinggi setelah kista radikuler, dengan predileksi lebih tinggi pada laki-laki daripada perempuan. $70 \%$ Kista dentigerous lebih ditemukan di mandibular dan $30 \%$ ditemukan pada maksila. ${ }^{1-3}$

Terdapat dua teori mengenai patogenesis kista dentigerous yaitu secara developmental dan inflamasi. Kista dentigerous secara developmental berkembang oleh karena adanya akumulasi cairan di antara epitel enamel dan enamel atau di dalam organ enamel. Tekanan yang disebabkan oleh gigi erupsi pada folikel gigi impaksi akan menghambat aliran keluar vena (stasis), hal ini akan memicu transudasi serum di sepanjang dinding kapiler dengan cepat. ${ }^{4}$ Peran IgG, IgM, IgA dan GAG di tingkat molekuler kemudian memicu peningkatan tekanan osmotik koloid dan mengakibatkan peningkatan tekanan hidrostatis dari cairan yang terkumpul, menyebabkan pemisahan folikel dari mahkota gigi dengan atau tanpa penurunan epitel enamel. ${ }^{5}$ Kista dentigerous di lain sisi juga dapat disebabkan oleh inflamasi periapikal gigi sulung yang menyebar ke area intra folikel gigi permanen penggantinya. ${ }^{5-7}$ Peran mediator inflamasi seperti limfosit T, makrofag, neutrofil dan beberapa sitokin inflamatori lainnya disebutkan dapat memicu resorpsi tulang alveolar dan hiperplasia dari sel-se epitel kistik sehingga kemudian terbentuk kista dentigerous. ${ }^{5,7}$

Kista dentigerous jarang menimbulkan rasa sakit dan rasa tidak nyaman, kecuali apabila terjadi infeksi sekunder. Beberapa pasien mengeluh adanya pembengkakan dengan pertumbuhan lambat disertai rasa nyeri ringan, gigi susu yang tidak tanggal, kehilangan gigi permanen, adanya perubahan posisi gigi pada area yg terlokalisir, dan drainage, pada kondisi ini biasanya lesi telah mencapai ukuran $>2 \mathrm{~cm}^{8,9}$ Kista ini dapat menyebabkan resorpsi gigi yang berdekatan dan perubahan posisi gigi. Pada mandibula kista dentigerous dapat meluas ke arah posterior dan anterior, sedangkan kista dentigerous pada maksila dapat meluas sampai dasar orbital. ${ }^{10}$

Kista dentigerous seringkali ditemukan secara tidak sengaja pada pemeriksaan radiograf. Gambaran radiograf kista dentigerous berupa gambaran radiolusen unilokuler, well-defined dengan tepi sklerotik dan berhubungan dengan mahkota gigi yang tidak erupsi. Evaluasi radiograf merupakan prosedur yang diagnostik yang penting untuk mendeteksi perluasan lesi yang besar, identifikasi lesi dengan struktur anatomi yang di dekatnya dan penilaian tepi lesi untuk menentukan adanya kemungkinan pertumbuhan yang agresif. ${ }^{10}$ 
Modalitas pencitraan konvensional seperti radiograf panoramik dan periapikal merupakan modalitas pencitraan yang biasa digunakan oleh para praktiksi untuk kebutuhan penunjang diagnosis dan rencana perawatan di bidang kedokteran gigi. Informasi yang diberikan kedua modalitas ini memiliki beberapa keterbatasan yakn struktur anatomi yang 3-dimensi ditampilkan dalam bentuk 2-dimensi, sehingga dapat terjadi superimposisi struktur anatomi. Kelemahan modalitas pencitraan 2-dimensi lainnya antara lain seperti keterbatasan observasi obyek pada arah bukal-lingual dan adanya distorsi geometris obyek. Beberapa dekade ini telah berkembang pesat aplikasi teknologi pencitraan CBCT (cone beam computed tomography) yang dapat memberikan gambaran obyek 3-dimensi jaringan maksillofasia dengan distorsi yang lebih minimal daripada modalitas 2-dimensi dan dengan dosis radiasi yang relatif kecil bila dibandingkan dengan paparan $C T$ scan medis. CBCT merupakan teknologi pencitraan digital 3-dimensi yang sering digunakan dalam berbagai cabang ilmu kedokteran gigi. ${ }^{11}$

Laporan kasus ini akan memaparkan tiga kasus berbeda yang menunjukkan beberapa variasi gambaran radiograf kista dentigerous dengan menggunakan modalitas pencitraan CBCT.

\section{LAPORAN KASUS}

\section{KASUS 1}

Seorang laki-laki berusia 30 tahun datang dengan keluhan tidak nyaman pada bagian belakang rahang bawah ketika mengunyah makanan. Pemerikaan klinis menunjukkan adanya sedikit pembengkakan pada bagian posterior kanan dan kiri mandibular, warna gusi normal. Pemeriksaan CBCT dilakukan untuk evaluasi kasus ini. Pada potongan coronal (Gambar 1), sagittal (Gambar 2) dan axial (Gambar 3) terdapat gambaran gigi impaksi 48 disertai dengan lesi radiolusen di bagian inferior mahkota gigi impaksi 48, berbentuk seperti kantung, berbatas jelas dan tegas. Tepi inferior lesi bersinggungan dengan kanalis mandibularis. Lesi berukuran 9,8mm x 11,9 x $11,1 \mathrm{~mm}$. Lesi meluas sampai ke bagian bukal akar distal gigi 47. Radiodiagnosis pada kasus tersebut di atas adalah kista dentigerous.

\section{KASUS 2}

Seorang wanita usia 53 tahun datang dengan keluhan bengkak pada langit-langit tumbuh sejak beberapa 10 bulan yang lalu, tidak terasa sakit, penderita mengeluh hidung buntu sejak 1 bulan terakhir. Pemeriksaan klinis tampak pembengkakan pada palatum, konsistensi keras, warna mukosa

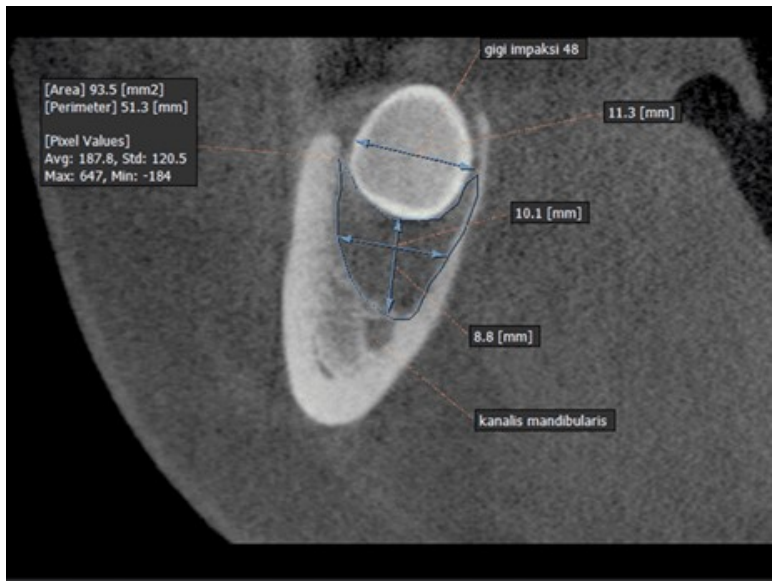

Gambar 1. Potongan coronal CBCT gigi 48 terdapat gambaran radiolusen bentuk oval, well-defined, terkortikasi pada bagian inferior mahkota gigi 48

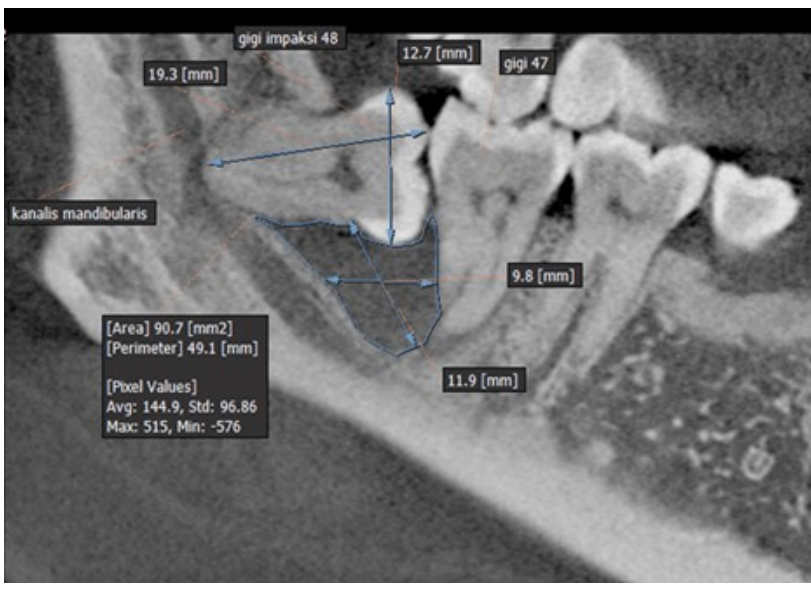

Gambar 2. Potongan sagital CBCT gigi 48 tampak gambaran radiolusen oval, welldefined, terkortikasi pada bagian mesial dari mahkota sampai akar gigi 48

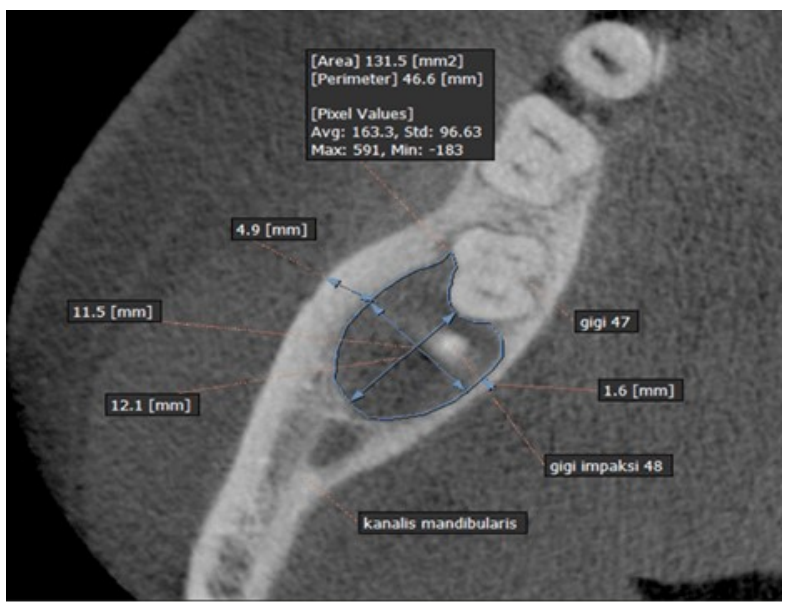

Gambar 3. Potongan axial CBCT gigi 48 terdapat gambaran radiolusen bentuk oval, well-defined, terkortikasi pada bagian distal gigi 47 


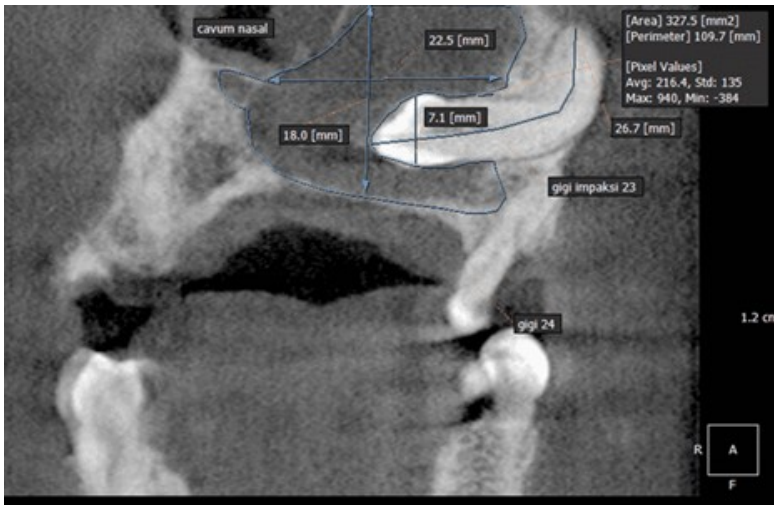

Gambar 4. Potongan koronal pada radiograf $\mathrm{CBCT}$ terdapat gambaran gigi impaksi 23 dengan posisi horizontal, dengan mahkota gigi impaksi masuk ke dalam konka nasalis

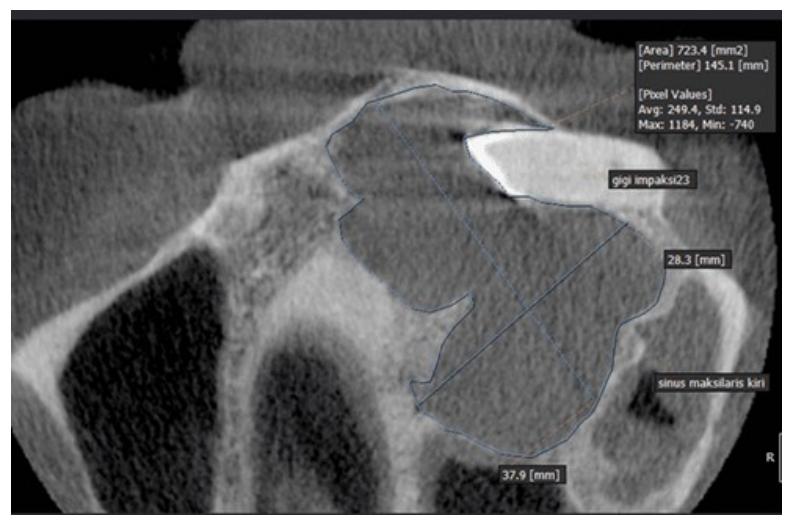

Gambar 6. Potongan axial CBCT terdapat gambaran gigi impaksi $23 \mathrm{di}$ dalam konka nasalis, terdapat gambaran radiolusen mengelilingi gigi impaksi dan memenuhi cavum nasal dan mendesak sinus maksilaris kiri

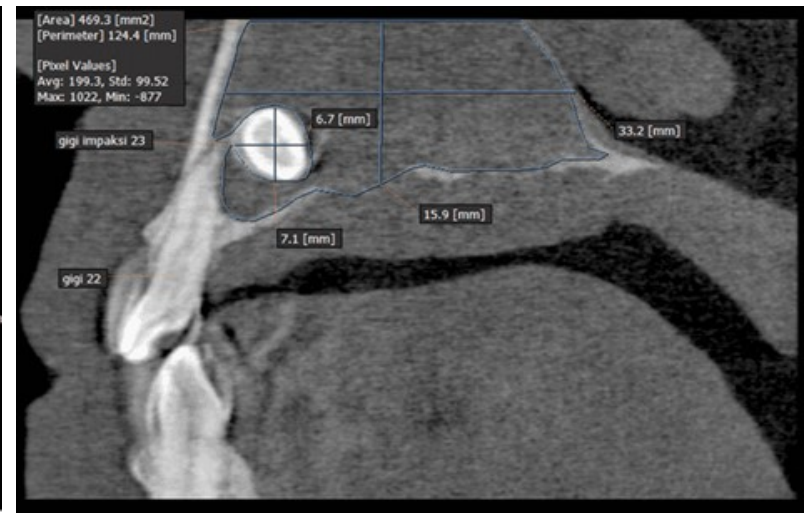

Gambar 5. Potongan sagital pada radiograf $\mathrm{CBCT}$ terdapat gambaran gigi impaksi 23 di dalam cavum nasal, terdapat gambaran radiolusen mengelilingi gigi impaksi dan memenuhi cavum nasal

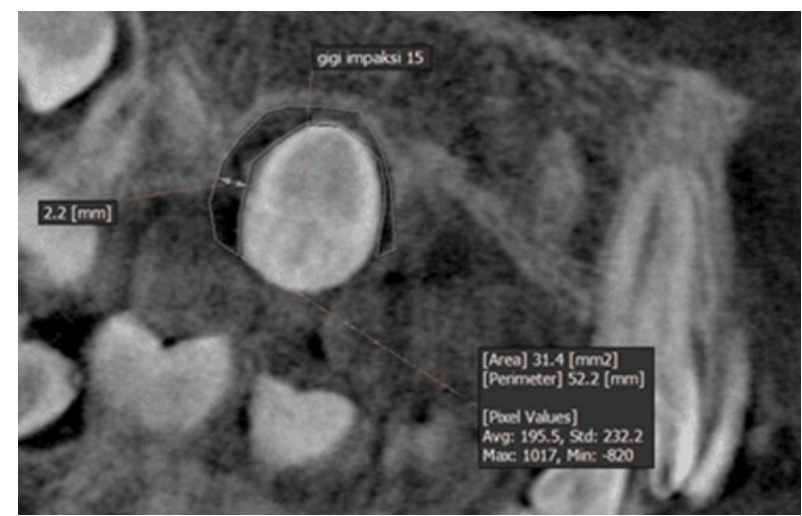

Gambar 7. Potongan sagital CBCT terdapat gigi impaksi 15 dengan posisi palatoversi di antara gigi 14 dan 16, serta tampak adanya area radiolusen di sekeliling mahkota gigi

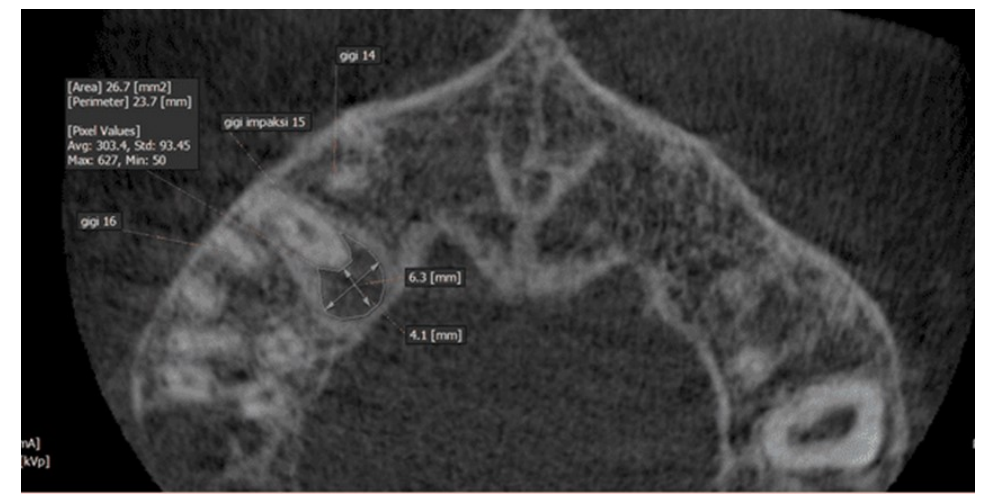

Gambar 8. Potongan axial CBCT gigi impaksi 15 menunjukkan gambaran radiolusen oval, welldefined d i sekitar mahkota gigi

normal. Berdasarkan hasil pemeriksaan CBCT pada potongan coronal (Gambar 4) terlihat gigi impaksi 23 pada apikal gigi 24. Pada potongan coronal, sagittal (Gambar 5) dan axial (Gambar 6) terdapat gambaran radiolusen berbatas jelas dan tegas, berbentuk oval. Lesi meluas hingga cavum nasal kir sampai nasal septum, lesi menyebabkan kerusakan dasar cavum nasal kiri dan tulang kortikal palatal, menyebabkan penipisan tulang kortikal bukal, mendesak gigi 23 ke arah bukal, serta menyebabkan ekspansi maksila ke arah bukal. Lesi berukuran $\pm 28.3 \mathrm{~mm} \times 37.9 \mathrm{~mm} \times 18 \mathrm{~mm}$. Berdasarkan pemeriksaan klinis dan radiografi ditegakkan diagnosis kista dentigerous dengan differential diagnosis ameloblastoma unikistik.

KASUS 3

Seorang anak laki-laki berusia 13 tahun akan melakukan perawatan orthodonsia, penderita dirujuk ke instalasi radiologi oleh dokter yang merawat untuk pemeriksaan gigi yang tidak erupsi. Berdasarkan hasil pemeriksaan CBCT potongan sagital tampak gambaran gigi impaksi 15 dengan posisi palatoversi di antara gigi 14 dan 16 (Gambar 7). Bagian mahkota gigi impaksi 15 menembus kortikal palatal. Pada bagian mahkota gigi impaksi 15 terdapat gambaran radiolusen berbentuk oval berbatas jelas dengan ukuran $6.3 \times 4.1 \times 2.2 \mathrm{~mm}$ (Gambar 8). Berdasarkan pemeriksaan klinis dan radiografi ditegakkan diagnosis kista dentigerous. 
Konfirmasi dari hasil pemeriksaan HPA yang diambil pada saat pencabutan gigi 48 (Kasus 1), 23 (kasus 2) dan 15 (kasus 3) menunjukkan lesi kista dentigerous.

\section{DISKUSI}

Kista dentigerous merupakan kista perkembangan yang paling sering dijumpai dibandingkan dengan kista perkembangan lainnya. Kista ini lebih sering terjadi pada laki-laki daripada perempuan dengan perbandingan 2.33:1, tanpa adanya predileksi ras. Kista dentigerous sering terjadi pada usia dekade 2 dan 3. Pada umumnya kista dentigerous terjadi soliter, bilateral kista dentigerous ditemui pada penderita syndrome cleidocranial dysplasia dan mucopolysaccharidosis (tipe VI). Beberapa kasus kista kista dentigerous berhubungan dengan gigi supernumerary dan odontoma. Kista dentigerous yang berhubungan dengan odontoma berkisar $27.6 \%$ kasus. ${ }^{12,13}$

Kista dentigerous secara klinis pada umumnya asimtomatis, pembengkakan tumbuh lambat, dan terdapat gigi yang tidak erupsi. Pada kasus 1 dan 3 pasien tidak mengeluh adanya pembengkakan, penderita hanya mengeluhkan adanya gigi yang tidak erupsi. Kista dentigerous pada kasus ke 1 dan 3 ditemukan secara tidak sengaja pada pemeriksaan radiograf. Berbeda hal nya dengan pada kasus 2 dimana penderita mengeluhkan adanya pembengkakan pada palatum, hidung buntu, dan keluhan keluar cairan dari hidung, hal ini karena kista dentigerous tumbuh membesar hingga menyebabkan ekspansi pada maksila, meluas sampai cavum nasal, hingga mendorong gigi impaksi ke cavum nasal. Beberapa laporan kasus juga menjabarkan kasus serupa yang agresif dimana kista dentigerous secara ekspansif mendesak gigi impaksi bersangkutan hingga terletak ektopik atau sepenuhnya berada di dalam sinus maksilaris dan dasar dinding orbita. Gambaran tersebut juga umumnya memberikan gejala klinis yang sama seperti sinusitis, nyeri wajah, sakit kepala hingga pembengkakan yang terlihat jelas secara klinis layaknya kasus 2. Pada kasus yang lebih parah dan sangat jarang terjadi, kista dentigerous dapat menyebabkan kerusakan pada saraf infraorbital hingga menyebabkan parastesi ataupun saraf kanalis alveolaris inferior pada mandibula. ${ }^{14,15}$

Pemeriksaan radiograf penting untuk menegakkan diagnosa dan rencana perawatan pada kasus kista dentigerous. Radiograf panoramik merupakan modalitas pencitraan yang sering digunakan untuk menegakkan diagnosa, walaupun pada kasus-kasus tertentu misalkan adanya gig impaksi pada maksila kurang jelas terlihat, hal ini disebabkan oleh karena struktur anatomi pada maksila seringkali terdapat ghost image dan superimposisi. Adanya superimposisi struktur anatomi yang cukup besar ini menyebabkan radiograf ekstraoral 2-dimensi kurang dapat memberikan informasi struktur internal lesi dengan jelas. Hubungan antara akar gigi dengan kanalis alveolar inferior mandibula pada radiograf 2 dimensi seringkali kurang jelas terlihat akibat adanya pembesaran pada lengkung rahang. Kekurangan yang ada pada radiograf 2-dimensi ini dapat dieliminasi oleh radiografi 3-dimensi seperti $\mathrm{CBCT}$ (cone beam computed tomography), dengan memberikan gambaran multiplanar dan rekonstruksi volume gambaran 3-dimensi yang lengkap. CBCT memiliki akurasi yang cukup baik untuk mengukur komponen tulang, dengan faktor kesalahan kurang dari 1\%. Hasil pemeriksaan CBCT pada kasus di atas mampu menyediakan informasi batas lesi, bentuk tepi lesi dan efek terhadap struktur yang berdekatan secara menyeluruh. ${ }^{16,17}$ Hasil pemeriksaan CBCT pada kasus 1 mampu menggambarkan secara detail hubungan lesi dengan kanalis mandibularis, begitu juga pada kasus 2 dimana lesi kista dentigerous tumbuh agresif, meluas ke cavum nasal hingga mendesak dinding medial sinus maksilaris.

Gambaran radiograf kista dentigerous berupa gambaran radiolusen, well-defined, unilokular, simetris di sekeliling mahkota gigi impaksi. Beberapa kista dentigerous yang besar memberikan gambaran multilokuler karena adanya trabekula tulang di dalam gambaran radiolusen, walaupun kista dentigerous bukan lesi multilokuler yang sebenarnya. Kista dentigerous yang besar dapat melibatkan beberapa gigi sekaligus dimana kista mengakibatkan migrasi hingga resorpsi gigi. Hal penting yang perlu diperhatikan dalam menegakkan diagnosa kista dentigerous adalah kista ini menempel pada cemento-enamel junction. ${ }^{18}$

Hubungan kista dentigerous terhadap mahkota gigi berdasarkan gambaran radiograf dapat dikelompokkan menjadi 3 variasi (Gambar 9). Variasi pertama kista terletak di tengah gigi atau juga disebut sebagai kista dentigerous sentral, terdapat gambaran radiolusen mengelilingi mahkota gigi, sehingga mahkota gigi berada di dalam lumen kista. Gambaran radiologis tipe ini terlihat pada kasus 3, dimana terdapat gambaran radiolusen berbentuk oval, well-defined, terkortikasi yang menempel pada bagian mahkota gigi kaninus RB. Kista dentigerous variasi sentral mengelilingi mahkota gigi secara simetris dan mendorong gigi ke arah yang berlawanan dengan arah erupsi sehingga gigi dapat terletak jauh di dekat border inferior mandibula, ramus ascendes ataupun jika terjadi pada rahang atas dapat terletak di dalam sinus maksilaris hingga dasar nasal atau orbital. Variasi kedua, kista berada di sisi lateral gigi, kista berkembang di sepanjang akar gigi dan hanya sebagian mengelilingi mahkota. Variasi kista dentigerous ini terlihat pada kasus 1, dimana terdapat gambaran radiolusen berbentuk oval, welldefined, unilokuler pada sisi mesial gigi impaksi 48 . Kista dentigerous lateral muncul akibat adanya dilatasi dari folikel pada satu sisi mahkota, pada umumnya ditemukan pada gigi yang erupsi sebagian dengan sisi superiornya yang terkespos. Variasi ketiga, dimana kista mengelilingi mahkota hingga permukaan akar, sehingga seluruh gigi masuk di dalam kista yang disebut sebagai kista dentigerous sirkumferensial. Gambaran radiologis kista dentigerous ini terlihat pada kasus 2, dimana 


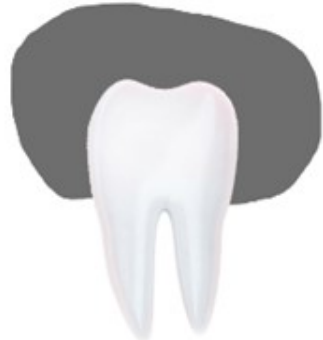

(a)

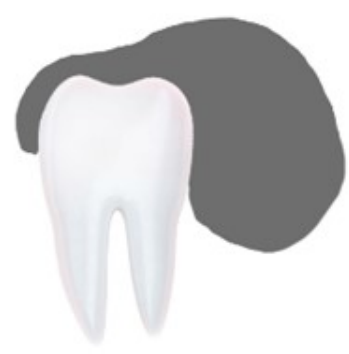

(b)

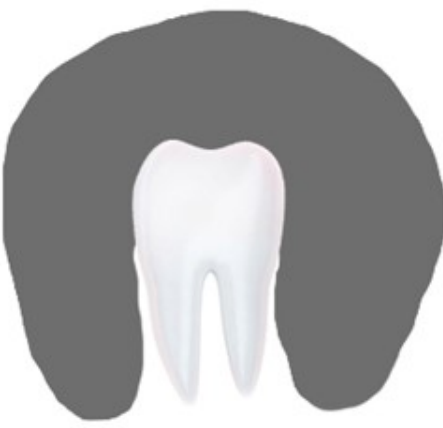

(c)

Gambar 9. Ilustrasi variasi gambaran radiologis kista dentigerous: (a) sentral, (b) lateral, dan (c) sirkumferensial

kista tumbuh agresif dan hampir menutupi seluruh permukaan gigi. ${ }^{19,20,25}$

Kista dentigerous seringkali sulit dibedakan dengan hiperplasia folikel, odontogenic keratocyst ameloblastik fibroma dan ameloblastoma unikistik. Kista dentigerous dapat dibedakan dengan hiperplasia folikel dengan mengevaluasi ada/ tidaknya displacement gigi atau ekspansi tulang. Ukuran folikel gigi normal sebesar 2-3 mm, apabila ruang folikel gigi mencapai ukuran $5 \mathrm{~mm}$, maka dapat dianggap sebagai kista dentigerous. Pemeriksaan lesi 4-6 bulan selanjutnya diperlukan untuk mendeteksi adanya pembesaran lesi dan pengaruh lesi terhadap jaringan sekitar yang menjadi ciri khas kista. ${ }^{18}$ Pada beberapa laporan kasus disebutkan bahwa kista dentigerous juga dapat menimbulkan komplikasi atau berhubungan dengan kasus yang lebih serius seperti ameloblastoma dan squamous cell carcinoma yang diduga berasal dari transformasi epithelial lining kista ataupun mucoepidermoid carcinoma yang berasal dari sel mucus pada tepi kista. ${ }^{21-23}$ Tindakan follow-up pada pasien dengan kasus yang diduga sebagai sebuah kista dentigerous menjadi penting untuk diagnosis dini guna tercapainya kesembuhan dan keberhasilan perawatan.

Odontogenic keratocyst (OKC) secara radiografis dapat dibedakan dengan kista dentigerous berdasarkan derajat ekspansi lesi, pada OKC ekspansi tulang ke arah bukal palatal minimal, jarang meyebabkan resorbsi gigi yang berada di sekitar lesi, dan lesi terjadi pada daerah apikal gigi impaksi. Kista dentigerous hampir tidak bisa dibedakan dengan ameloblastoma unikistik dan ameloblastik fibroma secara radiografis, dan hanya bisa dibedakan dengan pemeriksaan histopatologis (HPA), kecuali apabila kedua lesi ini memiliki struktur internal mixed radiopak dan radiolusen. ${ }^{18}$ Pada potongan axial radiograf 3-dimensi, sebagian besar kista dentigerous menunjukkan adanya ekspansi ke satu arah terutama ke arah cortical plate bukal karena ketebalan tulang pada sisi ini lebih tipis. Berbeda halnya dengan ameloblastoma yang jauh lebih agresif dan cenderung mengalam ekspansi ke arah bukal dan lingual. ${ }^{24}$

\section{SIMPULAN}

Kista dentigerous merupakan kista perkembangan yang berhubungan dengan gigi impaksi dan memiliki karakteristik radiograf tersendiri. Hasil pemeriksaan CBCT menunjukkan adanya variasi karakteristik radiograf kista dentigerous pada ketiga kasus di atas yakni kista dentigerous dengan gambaran sentral, lateral dan sirkumferensial. Pemeriksaan radiografi CBCT merupakan alat yang sangat berguna untuk diagnosis dan rencana perawatan karena CBCT memberikan gambaran 3-dimensi dengan memberikan data yang lengkap dan akurasi yang cukup tinggi dalam identifikasi lesi.

\section{DAFTAR PUSTAKA}

1. Devi P, Thimmarasa VB, Mehrotra V, Agarwal M. Multiple dentigerous cysts: a case report and review. J Maxillofac Ora Surg. 2015;14(Suppl 1):47-51. doi:10.1007/s12663-011-02803

2. Dinkar AD, Dawasaz AA, Shenoy S. Dentigerous cyst associated with multiple mesiodens: a case report. J Indian Soc Pedod Prev Dent. 2007;25(1):56-59. doi:10.4103/09704388.31994

3. Evren Ustuner MD, Suat Fitoz MD, Cetin Atasoy MD, Ilhan Erden MD, Serdar Akyar MD. Bilateral maxillary dentigerous cysts: a case report. Oral Surg Oral Med Oral Pathol Oral Radiol Endod.2003. 95:632-635. https://doi.org/10.1067/ moe.2003.123

4. Robinson RA. Diagnosing the most common odontogeniccystic and osseous lesions of the jaws for the practicing pathologist. Modern Pathology.2017. 30: S96S103. https://doi.org/10.1038/modpathol.2016.191

5. Pant B, Carvalho K, Dhupar A, Spadigam A. Bilateral nonsyndromic dentigerous cyst in a 10-year-old child: A case report and literature review. Int J App Basic Med Res 2019;9:58-61. doi:10.4103/ijabmr.IJABMR 205_18

6. Shetty RM, Dixit U. Dentigerous Cyst of Inflammatory Origin. International Journal of Clinical Pediatric Dentistry, September-December 2010;3(3):195-198. doi: 10.5005/jpjournals-10005-1076

7. Benn A, Altini M. Dentigerous cysts of inflammatory origin: a clinicopathologic study, Oral Surgery, Oral Medicine, Oral Pathology, Oral Radiology, and Endodontics. 1996; 81(2): 203 -209. https://doi.org/10.1016/S1079-2104(96)80416-1

8. Bodner L, Woldenberg Y, Bar-Ziv J. Radiographic features of large cystic lesion of jaws in children. Pediatric Radiology 2003;33(1):3-6. doi:10.1007/s00247-002-0816-2

9. Aggarwal C, Sharma A, Grover N, Mohideen K. Case series of dentigerous cyst with rare association of maxillary premolar maxillary lateral incisor and mandibular canine. Journal of Science.2014; 4(8): 522-528. 
10. Duhan R., Tandon S., Vasudeva S., Sharma M. Dentigerous Cyst in Maxillary Sinus Region: A Case Report and Outline of Clinical Management for Paediatric Dentists. Journal of Dental and Medical Science.2015; $14(8$ ): 84-88. doi 10.9790/0853-14878488

11. Vidya L, Ranganathan K, Praveen B, Gunaseelan $R$ Shanmugasundaram $S$. Cone-beam computed tomography in the management of dentigerous cyst of the jaws: A report of two cases. Indian Journal of Radiology and Imaging. 2013; 23 (4);342-345.

12. Shear M, Speight PM. Cysts of the oral and maxillofacia region. 4th ed. USA: Blackwell Publishing Professional; 2007. Dentigerous cyst; pp. 59-75.

13. Ustuner E, Fitoz S, Atasoy C, Erden I, Akyar S. Bilateral maxillary dentigerous cysts: a case report. Oral Surg Oral Med Oral Pathol Oral Radiol Endod. 2003. 95:632-635. https://doi.org/10.1067/moe.2003.123

14. Rosdiana N, Pramanik F. Gambaran radiografi impaksi ektopik molar tiga disertai kista dentigerous dalam sinus maksilaris pada radiograf CBCT 3D. Jurnal Radiolog Dentomaksilofasial Indonesia 2019;3(2)11-4. https:// doi.org/10.32793/jrdi.v3i2.485

15. Hutomo FR, Pratiwi ES, Kalanjati VP, Rizqiawan $A$ Dentigerous cyst and canine impaction at the orbital floor. Fol Med Indones. 2019;55:234-238. http:// dx.doi.org/10.20473/fmi.v55i3.15508

16. Ludlow JB, Laster WS, See M, Bailey L, Hershey HG. Accuracy of measurements of mandibular anatomy in cone beam computed tomography images. Oral Surg Oral Med Oral Pathol Oral Radiol Endod. 2007;103(4):534-542. doi:10.1016/ j.tripleo.2006.04.008
17. Deana NF, Alves N. Cone Beam CT in Diagnosis and Surgical Planning of Dentigerous Cyst. Case Reports in Dentistry. 2017. https://doi.org/10.1155/2017/7956041

18. White SC, Pharoah MJ. Oral Radiology Principles and Interpretation. Ed 7. Elsevier Mosby. Missouri. 2014.

19. Mamatha NS, Krishnamoorthy B, Shruthi R, Navin HK. Inflammatory dentigerous cyst- report of two case. IJOCR 2014; 2(1):25-28

20. Shear $M$, Speight P. Cyst of the oral and maxillofacial region. $4^{\text {th }}$ ed. Black-well publishing. Bristol. 2007.

21. Kondamari SK, Taneeru S, Guttikonda VR, Masabattula GK Ameloblastoma arising in the wall of dentigerous cyst Report of a rare entity. J Oral Maxillofac Pathol. 2018;22 (Suppl 1):S7-S10. doi:10.4103/jomfp.JOMFP_197_15

22. Gay-Escoda C, Camps-Font O, López-Ramírez M, Vidal-Bel A. Primary intraosseous squamous cell carcinoma arising in dentigerous cyst: Report of 2 cases and review of the literature. J Clin Exp Dent. 2015;7(5):e665-e670. Published 2015 Dec 1. doi:10.4317/jced.52689

23. Razavi SM, Yahyaabadi R, Khalesi S. A case of centra mucoepidermoid carcinoma associated with dentigerous cyst. Dent Res J (Isfahan). 2017;14(6):423-426. doi:10.4103/1735-3327.218564

24. White SC, Pharoah MJ. Oral radiology: principles and interpretation. $6^{\text {th }}$ ed. New Delhi. Mosby. 2004:p368

25. Jendi, S.K., Shaikh, S. The Tooth Crossing the Confinement of Mandible: An Unique Expression of Central Variety of Dentigerous Cyst. Indian J Otolaryngol Head Neck Surg. 2019; 71:860-864. https://doi.org/10.1007/s12070-019-01614-0 